\title{
RESOLUSI KONFLIK SOSIAL KEAGAMAAN DI KOTA BANDUNG
}

\author{
Zulfiqri Sonis Rahmana \\ Program Studi Studi Agama Agama UIN Sunan Gunung Djati Bandung \\ Jl. AH. Nasution No. 105 Kota Bandung \\ E-mail : zoelsangksc@gmail.com
}

\begin{abstract}
Religion must be a source of social order and inner peace as something that glamorize and glorify, and make a civilized man. Implementation of religious teachings should be a guideline for human life in order to achieve happiness together. However, in doing social life of human society faced with three problems, namely inability, powerlessness and uncertainty. So today, especially in Bandung, often socio-religious conflict played by the followers of the religion itself. Ironically, the religious teachings of the estuary is often seen as a conflict. This is the dissonance between theory and facts, causing a mismatch. Thus, the researchers want to analyze to these problems, by focusing research on socio-religious conflict resolution in Bandung, whether the function of religion as a cause of conflict or even as conflict resolution.
\end{abstract}

Keywords:

Religion, Conflict, Social

\begin{abstract}
Abstrak
Agama seharuhnya menjadi sumber tatanan masyarakat dan perdamaian batin sebagai sesuatu yang mengagungkan dan memuliakan, serta membuat manusia beradab. Implementasi dari ajaran agama harusnya menjadi pedoman bagi kehidupan manusia agar tercapainya kebahagiaan bersama. Akan tetapi, dalam melakukan kehidupan sosial masyarakat manusia dihadapkan kepada tiga permasalahan, yaitu katidakmampuan, ketidakberdayaan, dan ketidakpastian. Sehingga dewasa ini, khususnya di Kota Bandung, sering terjadi konflik sosial-keagamaan yang diperankan oleh para pemeluk agama itu sendiri. Ironisnya, ajaran agama kerap dipandang sebagai muaranya sebuah konflik. Hal inilah yang menjadi ketidakselarasan antara teori dengan fakta yang ada, sehingga menimbulkan ketidaksesuaian. Dengan demikian, peneliti hendak menganalisis terhadap permasalahan tersebut, dengan memfokuskan penelitian pada resolusi konflik sosial keagamaan di Kota Bandung, apakah fungsi agama sebagai penyebab terjadinya konflik atau malah sebagai resolusi konflik.
\end{abstract}

Kata Kunci:

Agama, Konflik, Sosial.

\section{A. PENDAHULUAN}

Konflik sosial-keagamaan sudah sering terjadi belakangan ini, baik yang bersifat internasional maupun nasional, bahkan ada yang bersifat lokal. Konflik ini berjenis destruktif dan berkepanjangan. Konflik yang paling hangat terjadi di Kota Bandung adalah konflik yang terjadi antara umat muslim dengan umat kristen akibat pendirian Gereja Batak Karo Protestan di Jl. Kawaluyaan Kota Bandung yang terjadi pada 6 April 2016. Dengan banyaknya konflik yang terjadi, diperlukannya sebuah resolusi atau penanganan yang biasa disebut dengan resolusi konflik. Resolusi konflik sebagai bidang spesialis tersendiri mulai berkembang pada era pasca perang dingin. ${ }^{1}$

Terkait konflik sosial-keagamaan yang terjadi di Kota Bandung, Pemkot Bandung sudah banyak menyediakan lembaga-lembaga atau forum-forum dalam penanganan atau resolusi, salah satunya adalah Kesatuan Bangsa dan Politik yang didalamnya terdapat sebuah forum yang bernama FKUB (Forum Kerukunan Umat Beragama). Namun, dalam

${ }^{1}$ Hugh Miall dkk., Resolusi Damai Konflik Kontemporer, terj. Tri Budi Sastrio, (Jakarta: PT RajaGrafindo Persada, 2002), hlm. 2. 
pelaksanaannya masih belum memberikan efek yang sangat dominan terhadap kerukunan yang terjadi di Kota Bandung, masih banyak masyarakat yang terus menerus menyimpan rasa ketidaksukaannya kepada umat nonagamanya.

Faktanya, konflik pembubaran KKR masih belum terselesaikan hingga saat ini, kedua belah pihak masih mempertahankan argumentasinya dan menyuarakan diri paling benar. Hal inilah yang tidak bisa dibiarkan begitu saja terjadi, karena jika dibiarkan maka konflik antar umat beragama ini akan semakin berkepanjangan dan dikhawatirkan akan bersifat destruktif dengan jalan kekerasan.

Kajian ini merupakan kajian analisis kasus dengan menggunakan metode observasi, wawancara, dan penelusuran kepustakaan. Kajian ini bertujuan untuk menganalisis resolusi konflik sosial-keagamaan di Kota Bandung, serta berusaha merumuskan fungsi agama dalam konflik sosial-keagamaan di Kota Bandung. Disisi lain, kajian ini berusaha memberikan pengertian secara gamblang mengenai fungsi agama yang sesungguhnya dalam sebuah konflik, apakah sebagai pemicu atau sebagai resolusi kepada masyarakat dan para pembaca.

Sistematika pembahasan dalam penelitian ini dibagi dalam tiga bagian. Pertama, akan menganalisis mengenai konflik sosial keagamaan di Kota Bandung. Kedua, akan menganalisis mengenai fungsi agama dalam konflik sosial-keagamaan di Kota Bandung. Pada pembahasan terakhir akan menganalisis Resolusi konflik-sosial keagamaan di Kota Bandung.

\section{B. HASIL DAN PEMBAHASAN}

\section{Konflik Sosial Keagamaan di Kota Bandung}

\section{a. Lokasi dan Waktu Konflik}

Peneliti dalam hal ini menentukan titik konflik berdasarkan data akurat dari Badan Kesatuan Bangsa dan Politik (Kesbangpol) Jawa barat dan Kota Bandung. Dalam data yang diperoleh peneliti dihasilkan empat titik lokasi terjadinya konflik sosial-keagamaan di Kota Bandung yang kemudian peneliti melakukan observasi yang mampu memperoleh informasi mengenai waktu terjadinya konflik tersebut yang kemudian peneliti rangkum dalam penjelasan berikut: (1) Lokasi konflik pendirian Gereja Rehobot terdapat di Jalan Soekarno Hatta No. 405 dan 309 RT 06 RW 06, Kel. Karasak, Kec. Astar, Kota Bandung dan Waktu kejadiannya itu pada 10 Maret 2016, (2) Lokasi konflik pendirian Gereja Katolik terdapat di Perumahan Grand Sharon RW 06, Kel. Cipamokolan, Kec. Rancasari, Kota Bandung dan Waktu kejadiannya itu pada tahun 2011, (3) Lokasi konflik pendirian Gereja Batak Karo Protestan terdapat di Jl Kawaluyaan No. 10, Kota Bandung dan Waktu kejadiannya itu pada 19 Desember 2013 dan 10 April 2016, dan (4) Lokasi konflik pendirian Mesjid Ahmadiyah terdapat di Jl Cisaranten Baru I, RT 05 RW 03, Kel. Cisaranten Kulon, Kec. Arcamanik, Kota Bandung dan Waktu kejadiannya itu pada tahun 2015.

\section{b. Penyebab Konflik}

Penyebab konflik dalam konflik sosialkeagamaan di Kota Bandung sedikitnya beragam dan juga agak sama, berikut beberapa penjelasan penyebab konflik dari berbagai titik kejadian konflik sosial-keagamaan di Kota Bandung, sebagai berikut: (1) Konflik pendirian Gereja Rehobot terjadi bukan karena agama, melainkan akibat kekeliruan perihal kelegalitasan IMB (Izin Mendirikan Bangunan) yang mestinya harus dilalui oleh beberapa tahapan dalam regulasi yang dirumuskan oleh pemerintahan daerah tentunya. Masyarakat Karasak ini sudah menjalankan ajaran agamanya dengan baik dengan konsep amar ma'ruf nahyi munkar, ketika ada kemungkaran maka akan dicegahnya. Maksud kemungkaran disini adalah kekeliruan perihal legalitas prosedural regulasi yang ditempuh oleh pihak Gereja Rehobot bukan perihal berbedanya agama antara mayoritas dan minoritas, (2) penyebab konflik pendirian Gereja Katolik adalah sama dengan konflik anatara warga Karasak dengan Gereja Rehobot, yaitu adalah permasalahan regulasi dalam mendirikan sebuah tempat 
peribadatan. Namun bedanya, konflik ini dipelopori oleh development yang memberikan respon agar didirikannya Gereja Katolik ketika warga hendak meminta didirikannya sebuah Mesjid. Sedangkan warga kala itu tidak setuju akan didirkanya Gereja di perumahan tercinta mereka sehingga terjadi konflik verbal antar warga yang muslim dengan katolik dan kedua pemuka agama dari mereka pun sama-sama sepakat bahwa bukan agama yang menyebabkan konflik ini terjadi, (3) Penyebab konflik pendirian gereja Batak karo Protestan dilatarbelakangi pada 17 Januari 2003 jemaat GBKP membeli sebidang tanah dan bangunan kosong bekas gudang di Jl. Kawaluyaan No.10 RT 06 RW 06 Kelurahan Jatisari Kecamatan Buahbatu. Pada bulan April tahun 2003 jemaat GBKP mengajukan permohonan izin bangunan untuk merenovasi gudang tersebut dan menjadikannya Gedung Serba Guna, dan Pemerintah Kota Bandung mengeluarkan Izin untuk Gedung Serba Guna pada tanggal 29 Oktober 2003. ${ }^{2}$

Pada Bulan Mei tahun 2007, Gedung Serba Guna mulai digunakan oleh jemaat GBKP dan masyarakat RW 06 dengan pembagian jadwal senin sampai sabtu gedung dipakai bersama antara jemaat GBKP dan masyarakat RW 06 untuk berbagai kegiatan, diantaranya olahraga badminton, Resepsi Pernikahan, Rapat masyarakat dengan pemerintah Kelurahan Jatisari, dll. sedangkan hari minggu dipakai kegiatan pembinaan iman jemaat GBKP.

Pada bulan Oktober tahun 2007 sebagian warga RW 06 Kelurahan Jatisari Kecamatan Buah Batu Kota Bandung menyampaikan unjuk rasa keberatan penggunaan Gedung Serba Guna untuk kegiatan Pembinaan Iman Jemaat GBKP karena bangunan serba guna bukan rumah ibadat. Selanjutnya disepakati bahwa kegiatan pembinaan iman dihentikan sampai dikeluarkan izin dari Pemerintah Kota Bandung, sedangkan kegiatan kemasyarakatan masih tetap berlanjut.

Sejak saat itu diupayakanlah untuk mendapatkan izin Rumah Ibadah (gereja).

${ }^{2}$ Wawancara dengan Pendeta Tony, Pemuka Agama Gereja BKP. Pada 18 Maret 2018 Pukul 13.00 WIB.
Setelah mendapat surat pernyataan dari 85 orang warga masyarakat yang ditandatangani dan dilampirkan foto copy Kartu Tanda Penduduk, lalu jemaat GBKP meminta pengantar dari RT dan RW 06 Kelurahan Jatisari untuk melengkapi dokumen mendapatkan Izin Mendirikan Bangunan (IMB) pembangunan Bangunan Gereja di Jl. Kawaluyaan No. 10 Kelurahan Jatisari Kota Bandung dari Pemerintah Kota Bandung.

Setelah mendapatkan surat pengantar dari RT dan RW, lalu meminta Rekomendasi dari Lurah Kelurahan Jatisari. Surat rekomendasi ditandatangani juga oleh Ka.Polsek Buah Batu, Danramil Buah Batu, Camat Buah Batu, Ketua LPM Jatisari. Surat rekomendasi dari kelurahan ditandatangani tanggal 8 November 2011. Setelah mendapatkan surat Rekomendasi dari Lurah Kelurahan Jatisari, lalu meminta Rekomendasi dari Kecamatan Buah Batu. Surat rekomendasi dari kecamatan Buah Batu dikeluarkan dan ditandatangani tanggal 15 November 2011.

Setelah mendapatkan surat Rekomendasi dari Kecamatan Buah Batu, lalu meminta Rekomendasi dari Kementerian Agama Kota Bandung. Surat rekomendasi dari Kementerian Agama Kota Bandung dikeluarkan dan ditandatangani tanggal 21 November 2011. Setelah mendapatkan surat Rekomendasi dari Kementerian Agama Kota Bandung, lalu meminta pertimbangan tertulis dari Forum Kerukunan Umat Beragama Kota Bandung. Surat pertimbangan tertulis dari Forum Kerukunan Umat Beragama Kota Bandung dikeluarkan dan ditandatangani tanggal 1 Desember 2011.

Setelah mendapatkan surat pertimbangan tertulis dari Forum Kerukunan Ummat Beragama Kota Bandung, lalu Jemaat GBKP meminta pertimbangan tertulis dari Badan Kesatuan Bangsa Perlindungan dan Pemberdayaan Masyarakat Kota Bandung. Surat pertimbangan tertulis dari Kepala Badan Kesatuan Bangsa Perlindungan dan Pemberdayaan Masyarakat Kota Bandung dikeluarkan dan ditandatangani tanggal 25 Mei 2012. 
Setelah mendapatkan surat pertimbangan tertulis dari Badan Kesatuan Bangsa Perlindungan dan Pemberdayaan Masyarakat Kota Bandung, lalu Jemaat GBKP memohon surat Izin Mendirikan Bangunan (IMB) ke Walikota Bandung melalui Badan Pelayanan Perizinan Terpadu Kota Bandung. Sebelum menandatangani surat Izin Mendirikan Bangunan (IMB), Kepala Badan Pelayanan Perizinan Terpadu Kota Bandung, meneliti, melihat dan memeriksa keabsahan dokumen. Surat Izin Mendirikan Bangunan (IMB), Kepala Badan Pelayanan Perizinan Terpadu Kota dikeluarkan dan ditandatangani tanggal 20 Juni 2012. ${ }^{3}$

Setelah IMB terbit, pada tanggal 29 Juni 2012 kelompok yang mengatasnamakan diri umat Islam RT06 RW06 Jatisari didampingi ormas-ormas Islam melakukan penyegelan terhadap GBKP Jalan Kawaluyaan No.10. Namun GBKP Bandung Timur tetap mengedepankan musyawarah. Telah tercapai kesepakatan dengan warga RW06 Kelurahan Jatisari, pada hari senin tanggal 01 Oktober 2012 di kantor Camat Buahbatu, disepakati untuk "membuka gembok/ rantai di pintu gereja GBKP Bandung Timur Jl.Kawaluyaan No.10 Bandung" dan dinyatakan segala permasalahan dianggap selesai. Karena kesepakatan telah tercapai maka dimulailah pembangunan gedung gereja. Tetapi pada tanggal 19 Desember 2013 masyarakat muslim kawaluyaan melakukan demonstrasi ke kantor walikota untuk menghentikan pembangunan gereja ini. Mereka tidak mengakui lagi kesepakatan yang telah ditandatangani. Karena terus menerus menekan pihak walikota, hingga Walikota Bandung mengeluarkan surat pada tanggal 27 Februari 2014 perihal Validasi data warga yang tidak keberatan atas keberadaan GBKP Bandung Timur.

Pada tanggal 18 Desember 2015, setelah sekian lama gedung gereja tidak dapat dipergunakan untuk beribadah, Kepala Badan Pelayanan Perizinan Terpadu (BPPT) Kota Bandung mengadakan rapat di Kantor BPPT Jl. Cianjur No.34 - Bandung. Rapat ini

\footnotetext{
${ }^{3}$ Wawancara dengan Pendeta Tony, Pemuka Agama Gereja BKP. Pada 18 Maret 2018 Pukul 13.00 WIB.
}

dihadiri Kepala BKBPPM Kota Bandung, Camat Buahbatu, Lurah Jatisari, FKUB Kota Bandung, perwakilan Danramil kecamatan Buahbatu, Kapolsek kecamatan Buahbatu, RW 06 kelurahan Jatisari, serta perwakilan dari GBKP Bandung Timur. Kepala BPPT Drs. H. Ema Sumarna, M.Si, setelah meneliti semua berkas-berkas perizinan GBKP Bandung Timur, menyatakan bahwa semua persyaratan lengkap secara legal formal. Jadi pada rapat ini ditegaskan bahwa IMB Rumah Ibadah GBKP Bandung Timur yang terbit pada tanggal 20 Juni 2002 sah secara hukum maka harus difungsikan untuk tempat beribadah.

Maka atas nama Walikota Bandung, Kepala BPPT memerintahkan kepada Camat Buahbatu untuk melakukan musyawarah dengan warga dan kalau tetap keberatan dipersilakan untuk mengajukan gugatan ke PTUN. Camat berupaya mengundang warga RW06 Kelurahan Jatisari untuk melakukan musyawarah dengan pihak GBKP Bandung Timur di kantor Camat, namun mereka tidak mau hadir. Camat, Kapolsek dan Danramil mendatangi warga ke Masjid mereka, tetapi respon mereka tetap menolak. Namun saat ditawarkan untuk menggugat ke PTUN mereka tidak mau. ${ }^{4}$

Pihak Gereja menyadari bahwa resistensi masyarakat yang tidak setuju dengan keberadaan GBKP Bandung Timur masih kuat, namun pintu berdialog tertutup rapat. Pada sisi yang lain, gereja yang telah dibangun dengan izin resmi tidak dapat digunakan menjadi pergumulan berat. Maka pada tanggal 06 Maret 2016 dimulailah menggunakan gereja ini untuk beribadah. Sampai tanggal 3 April 2016 kami melakukan ibadah tanpa gangguan," demikian siaran pers GBKP Bandung Timur. Untuk meneguhkan keberadaan GBKP Bandung Timur, pada tanggal 4 Maret 2016 mengundang Walikota Bandung Ridwan Kamil untuk meresmikan GBKP Bandung Timur pada tanggal 10 April 2016, dan (4) Penyebab terjadinya konflik pendirian Mesjid Ahmadiyah karena hal yang

\footnotetext{
${ }^{4}$ Wawancara dengan Pendeta Tony, Pemuka Agama Gereja BKP. Pada 18 Maret 2018 Pukul 13.00 WIB.
} 
sama dengan konflik yang terjadi sebelumnya, yaitu diakrenakan perihal IMB yang menurut warga muslim non ahmadiyah masih keliru, disamping warga ahmadiyah disana hanya berjumlah 3 orang dan sangat anehnya bisa mengajukan pendirian Mesjid Ahmadiyah. Pernah terjadi adu mulut antara warga dan pihak Ahmadiyah, namun mereka tetap mengaku muslim hanya berbeda golongan. Hal ini membuat warga muslim Cisaranten geram dan menceri dukungan dari berbagai pihak.

\section{c. Resolusi Konflik}

Resolusi konflik dalam konflik sosialkeagamaan di Kota Bandung ini pun beranekaragam yang akan penelitii bahas juga kedalam beberapa penjelasan berikut: (1) Resolusi konflik yang diterapkan dalam konflik pendirian Gereja Rehobot sangat dipelopori oleh badan intelejen bagian kewaspadaan daerah Kesatuan Bangsa dan Politik (Kesbangpol) Jawa Barat yang langsung terjun ke tempat konflik terjadi. Setelah itu, mereka kemudian memulai proses dalam meyenyelesaikan konflik tersebut. Pertama, melalui pendekatan psikologis, dimana mereka melakukan penedekatan secara emosional dengan warga dan pihak Gereja serta menjalin komunikasi yang baik diantara keduanya. Kedua, mereka kemudian langsung melakukan sensus, seperti perhitungan warga yang setuju dan tidak, jumlah KTP yang terkumpul seberapa, dan lain sebagainya yang berkaitan dengan penyebab terjadinya konflik tersebut terjadi. Ketiga, melakukan koordinasi dengan FKUB (Forum Kerukunan Umat Beragama) yang merupakan organisasi dari naungan Kesbangpol sendiri. Keempat, bagian intelejen bidang kewaspadaan daerah berkolaborasi dengan pemuka agama yang ada pada FKUB beserta pemuka agama dari masyarakat tersebut melakukan gerakan toleransi, intinya masyarakat jangan samapai membawa-bawa truth claim nya masingmasing dalam permasalahan regulasi IMB tersebut. Mereka tentunya menyelesaikan konflik ini dengan ajaran agama yang luhur, mengajarkan kebaikan dan saling toleran. Sudah jelas bukan agama yang menjadi penyebab konflik, akan tetapi kekeliruan dalam perihal regulasi pembuatan IMB dan malah agama dalam konteks ajaran menjadi resolusi dalam penyelesaian konflik ini. Berbeda dengan Marx yang menyebutkan bahwa agama adalah salah satu faktor pemicu dalam sebuah konflik. Dalam kenyataanya, Talcoot Parsons lah yang sesuai dengan apa yang terjadi dalam konflik ini, yaitu agama sebagai faktor pemersatu umat dan sebagai resolusi dalam sebuah konflik, (2) Begitupun resolusi konflik sosial-keagamaan yang diterapkan pada konflik pendirian Gereja Katolik, penyelesaian konflik pada konflik ini adalah sama sebagaimana tahapan tahapan yang dilakukan oleh bagian intelejen bidang kewaspadaan daerah Kesatuan Bangsa dan Politik Jawa Barat yang pada tahapan awalnya mencari/melakukan pendeekatan secara emosional yang pada ujungnya memberikan/mengingatkan kedua belah pihak agar bisa hidup dengan penuh rasa toleran melalui nilai-nilai/ajaran agama yang berlaku bagi kedua belah pihak. Jelas, dalam konflik ini pun teori Marx lagi-lagi bertolak belakang dan teori Talcott Parsons yang saling tegak lurus, karena dalam konflik ini agama sebagai resolusi dalam penyelesaian konflik bukan sebagai pemicu sebuah konflik, (3) Resolusi konflik dalam penyelesaian konflik pendirian Gereja Batak Karo Protestan berbeda dengan dua tahapan resolusi konflik sebelumnya, tetapi dengan melalui beberapa Pemuka Agama dari masing-masing agama dengan mengingatkan agar senantiasa bisa meredam egonya dan memberikan beberapa-beberapa kajian setelah sholat yang bertemakan hubungannya dengan nonmuslim yang baik dan benar. Para Pemuka Agama senantiasa aktif dalam permasalah ini, karena merekamereka lah yang cenderung meredakan sedikitnya konflik ketika awal mula diundang hingga ke beberapa-beberapa percekcokan diantara keduanya. Hal ini daidasari oleh perkataan Ustadz Amang: "saya beserta para tokoh agama lainnya dari awal sudah senantiasa memberikan pengingat berupa ajaran toleran dan memberikan kajian atau 
halqah tentang yang berhuungan dengan nonmuslim".

Khsusus untuk konflik ini, badan Kesabangpol tidak turun langsung, karena terdapat beberapa agenda yang harus dikejar yang mereka langsung mendapatkan data entri dari pemerintahan setempat. “...Kami tidak langsung turun tangan ini, soalnya waktu itu ada sebuah agenda pertemuan di Jakarta, jadi konflik tersebut sudah masuk entry datanya ke kami lewat narasumber kami", tutur Pak Solihin kepada peneliti. ${ }^{5}$ Namun, proses penyelesaian ini terjadi ketika demo besarbesaran itu, dengan ditumbuhkan atau diingatkan nilai-nilai tolernasi bersama dan kala itu tercapai kesepakatan bahwa Aula itu beralih fungsi menjadi Aula Serba Guna, dan legal jika digunakan untuk peribadatan Protestan.

Proses penyelesaian konflik ini menurut analisa peneliti adalah audiensi anatara warga muslim Kawaluyaan yang tidak tahu dan merasa aneh dengan surat IMB yang terbit dengan pihak Gereja beserta dengan Pemerintahan. Didalamnya dijelaskan runtutan-runtutan yang sudah dijelaskan oleh Pendeta Tony dalam wawancara yang dilakukan peneliti, dari mulai cabang Bandung Timur Gereja Karo Protestan ini ada sampai dengan diterbitkannya IMB dari pemerintahan. Namun, yang menjadi letak permasalahannya adalah warga muslim Kawaluyaan tidak tahu dan tidak ada sosialisasi sebelumnya perihal perizinan Gereja ini, apalagi menggunakan aula yang senantiasa dipakai aula olahraga pada masyarkat Kawaluyaan.

Singkat cerita, masayarakat tahu bahwa sebagian daripada warga itu dipaksa menyetujui perizinan Gereja dengan embelembel uang dan sembako tanpa memberitahu warga lainnya yang jelas-jelas tidak setuju dengan pendirian Gereja tersebut. Dengan poin ini, warga muslim Kawaluyaan membantah IMB tersbut. Hingga pada akhirnya, terjadi kesepakatan yang melalui perdebatan yang pelik diantara kedua belah pihak, yaitu dengan

${ }^{5}$ Wawancara dengan Solihin, Selaku Bidang Kewaspadaan Daera Kesbangpol Jawa Barat. Pada 7 Maret 2018 Pukul 11.30 WIB. menggunakan Aula tersbut sebagai Aula serba guna, pihak Gereja boleh melakukan setiap peribadatan disana dan masyarakat pun boleh ketika memakai kegiatan keagamaan disana, apalagi melakukan kegiatan olahraga, dan (4) Resolusi dalam konflik pendirian Mesjid Ahmadiyah, Seperti biasa, proses peneyelesaian konflik ini dilakukan oleh para pemuka agama yang memang senantiasa mengingatkan nilai-nilai keagamaan dan kerukunan bersama, agar bisa hidup berdampingan. Mau dia bagian daripada Islam atau bukan, tetapi untuk masalah sosial mereka sama, sama-sama manusia yang memiliki hak yang sama pula, apalagi negara kita adalah negara yang plural yang harusnya bisa hidup rukun, damai, tentram berdampingan. Usaha lain pun dijalankan oleh pemerintah dengan mengeluarkan Peraturan Gubernur No. 12 Tahun 2011 Tentang Larangan Kegiatan Jemaat Ahmadiyah Indonesia di Jawa Barat. dengan melalui pencarian pendukung bagi warga muslim Cisaranten untuk menghalau pendirian Mesjid Ahmadiyah yang kemudian mendapat respon yang positif dari pemerintahan Jawa barat dengan menerbitkan Peraturan Gubernur No. 12 Tahun 2011 Tentang Larangan Kegiatan Jemaat Ahmadiyah Indonesia di Jawa Barat yang peneliti dapatkan langsung naskahnya dari Instansi Kesbangpol Jawa Barat. Namun, bertolak belakang dengan yang disampaikan Pak Dikdik dengan realitas yang ada dalam masyarakat, nyatanya mesjid Ahmadiyah ini berhasil dibangun dengan nama Mesjid Fadhlullah, mesjidnya dua tingkat, suka dipakai Jum'atan dan kajian-kajian. dan letak Peraturan Gubernur tersebut masih dipertanyakan masyarakat dan hingga sekarang masih belum ada kejelasan dan dalam proses tindak lanjut dari warga kepada pemerintahan agar pemerintah peka terhadap masalah yang vital ini. Impact nya membuat warga muslim dengan Ahmdiyah ini cenderung suka saling melempar ujaran-ujaran yang sifatnya menyindir dan sempat konflik verbal.

Untuk itu, para pemuka agama dari kedua belah pihak senantiasa kembali mengajarkan 
ajaran agamanya dengan saling hidup rukun, jangan sampai melibatkan masalah kebenaran dari masing-masing kelompok kedalam masalah regulasi yang disediakan pemerintah dalam mendirikan bangunan tempat peribadatan. Jelas sekali disini agama bukan penyebab terjadinya sebuah konflik, akan tetapi menjadi alternatif penyelesaian konflik dan masih berproses dalam menyelesaikan konflik, walaupun konflik ini masih belum terselesaikan secara penuh.

\section{Fungsi Agama dalam Konflik Sosial Keagamaan di Kota Bandung}

Fungsi agama ini merupakan status dari agamanya itu sendiri dalam konflik sosial keagamaan di Kota Bandung. Terdapat dua fungsi yang sama-sama kuat dan sama-sama bertentengan yang juga dipelopori oleh tokoh yang cukup terkenal. Fungsi agama yang pertama adalah agama sebagai mauranya sebuah konflik atau penyebab terjadinya konflik yang bernuansa agama, hal itu dibuktikan oleh paparan daripada Karl Marx yang kala itu melihat pada kaum borjuis dan kaum proletar. Sedangkan fungsi agama yang satunya adalah agama sebagai resolusi dalam sebuah konflik. Hal itu disebutkan oleh Talcott Parsons melalui teori sosiologi fungsionalnya, dimana berliau mengatakan bahwasanya agama itu merupakan salah satu unsur penguat dalam masyarakat dan memberikan fungsi sebagai pemersatu umat dalam sebuah masayarakat, begitu juga dalam sebuah konflik yang mana agama ini mampu menjadi sebuah sintesis dari setiap tesa dan antitesa yang melakukan sebuah konflik yang bernuansa agama.

Peneliti menganalisis beberapa konflik sosial keagamaan yang telah terjadi di Kota Bandung. Sebelum peneliti memaparkan analisisnya menganai peranan agama ini, peneliti juga menemukan titik temu, dimana memang pada kenyataanya, Kota Bandung ini tergolong masyarakatnya sangat toleran, terbukti hanya terdapat 4 kasus saja yang terjadi disebabkan oleh beberapa penyebab khusus, tidak sampai memakan korban dan juga tidak sampai merusak tempat peribadatan yang sempat terjadi di Papua, Maluku, atau bahkan di konflik Poso.

Bisa dilihat dalam pembahasan sebelumnya mengenai konflik-konflik sosial keagamaan yang sudah terjadi, agama disitu ternyata menjadi resolusi dalam menyelesaikan konflik-konflik tersebut, walaupun hanya ada satu konflik yang masih belum bisa terselesaikan, karena memang berhubungan juga dengan pemerintahan. Akan tetapi, sebagian besar dan bahkan mayoritas mengatakan dan terlihat bahwasanya agama dalam konflik sosial keagamaan di Kota Bandung ini fungsinya positif dan senada dengan teori fungsionalismenya Talcott Parsons yang mengatakan bahwasanya agama merupakan resolusi dalam menyelesaikan sebuah konflik yang bernuansa agama. Hanyasaja, terdapat beberapa oknum yang memang dalam pemikirannya mengkristal kehendak dari masing-masing ego yang tercurahkan kedalam bentuk sosial kemasyarakatan, yang mengakibatkan terjadinya sebuah konflik.

\section{Resolusi Konflik Sosial Keagamaan di Kota Bandung}

Resolusi dalam menyelesaikan konflik sosial keagamaan di Kota Bandung, pada dasarnya dipegang oleh kementerian Agama dan juga Pemerintahan Kota Bandung, juga pemerintahan Jawa barat dengan Badan Kesatuan Bangsa dan Politiknya, juga melalui Forum Kerukunan Umat Beragama wilayah Jaw Barat yang berkolaborasi dengan Forum Kerukunan Umat Beragama Kota Bandung. Cara yang ditempuhnya adalah dengan mengadakan sensus terlebih dahulu untuk menemukan data-data yang valid dan tidak rekayasa yang kemudian dilakukan rapat internal. Setelah itu, mereka mengundang dari masing-masing pihak yang bersimpangan dan hendak dilalui oleh beberapa kesepakatankesepakatan jikalau memang hasil daripada sensus tersebut seimbang.

Disatu sisi juga, selain daripada Kemenag dan FKUB yang memberikan ajaran-ajaran dan mengingatkan akan nilai-nilai keagamaan yang menjadi sumber daripada berperilaku baik, 
ramah, dan toleran, masyarakat sekitar pun melalui para pemuka agama menjarkan dan mengingatkan hal-hal yang sama dengan instansi keagamaan diatas. Sehingga sebagian besar, dan hanya satu saja yang masih belum terselesaikan. Namun, secara general agama disini sangatlah menjadi pionir utama dalam menyelesaikan atau meredam konflik sosial keagamaan di Kota Bandung.

\section{SIMPULAN}

Peneliti menemukan temuan bahwasanya masyarakat kota Bandung itu sangat toleran, walaupun masyarakatnya heterogen, namun dalam sejarahnya ini, bahkan sudah berpuluhpuluh tahun lebih, Kota Bandung hanya diidap oleh 4 konflik sosial keagamaan saja, yaitu: (1) Konflik antara warga muslim Karasak dengan Gereja Rehobot; (2) Konflik anatara warga muslim Cipamokolan dengan Gereja Katolik; (3) Konflik anatara warga muslim Kawaluyaan dengan Gereja Karo Protestan; dan (4) Konflik anatara warga muslim Cisaranten Baru I dengan Ahmadiyah. Keempat konflik ini pun sifatnya masih soft (lembut/tidak keras) seperti konflik sosial keagamaan yang terjadi di Papua, Poso, Maluku, ataupun daerah lainnya.

Selanjutnya, seperti yang kita ketahui bahwa agama tentunya mempunya dua fungsi yang berkontradiksi, yaitu menurut Talcott Parsons adalah sebagai resolusi dalam menyelesaikan sebuah konflik dan menurut Karl Marx adalah sebagai pemicu atau penyebab konflik terjadi. Namun, fungsi agama di Kota Bandung ini adalah sebagai resolusi dalam menyelesaikan konflik sosial keagamaan yang selaras dengan teori fungsionalnya Talcott Parsons, karena dalam menyelesaikan atau minimalnya meredakan sebuah konflik sosial keagamaan yang terjadi di Kota Bandung itu melalui perspektif agama. Hal tersebut dibuktikan dengan indikator penyebab konflik pada semua konflik sosial keagamaan yang terjadi di Kota Bandung ini, yaitu diakibatkan oleh kejanggalankejanggalan Perizinan dalam IMB (Izin Mendirikan Bangunan) tempat peribadatan yang masing-masing lokasi memiliki tingkat kejanggalan yang berbeda-beda.
Selain itu, dapat dibuktikan pula dengan indikator resolusi konflik yang digagas oleh intelejen bidang kewaspadaan daerah Kesbangpol Jabar, sebagai berikut: (1) Melalui pendekatan psikologis, dimana mereka melakukan penedekatan secara emosional dengan warga dan pihak Gereja serta menjalin komunikasi yang baik diantara keduanya. (2) Mereka kemudian langsung melakukan sensus, seperti perhitungan warga yang setuju dan tidak, jumlah KTP yang terkumpul seberapa, dan lain sebagainya yang berkaitan dengan penyebab terjadinya konflik tersebut terjadi. (3) Melakukan koordinasi dengan FKUB (Forum Kerukunan Umat Beragama) yang merupakan organisasi dari naungan Kesbangpol sendiri. (4) Intelejen bidang kewaspadaan daerah berkolaborasi dengan pemuka agama yang ada pada FKUB beserta pemuka agama dari masyarakat tersebut melakukan gerakan toleransi, intinya masyarakat jangan samapai membawa-bawa truth claim nya masing-masing dalam permasalahan regulasi IMB tersebut. Mereka tentunya menyelesaikan konflik ini dengan ajaran agama yang luhur, mengajarkan kebaikan dan saling toleran.

\section{DAFTAR PUSTAKA}

\section{Buku}

Affan, Gaffar. 2001. Politik Indonesia Tradisi Menuju Demokrasi. Pustaka Pelajar, Yogyakarta.

Ali Imron, M. 2015. Sejarah Terlengkap Agama-Agama di Dunia. IRCiSoD, Yogyakarta.

Ali, Hasymi. 1988. Konflik Dunia Ketiga dan Keamanan Dunia. Bina Aksara, Jakarta.

Ali, Mukti. 1987. Beberapa Persoalan Agama Dewasa Ini. Rajawali Pers, Jakarta.

Alma, Buchari. 2009. Belajar Mudah Penelitian. Alfabeta, Bandung.

an Nabhani, Taqiyuddin. 2001. Peraturan Hidup dalam Islam. Pustaka Thariqul 'Izzah, Bogor.

Arifin. 1994. Menguak Misteri Ajaran AgamaAgama Besar. Golden Trayon, Jakarta.

Arikunto, Suharsini. 2006. Prosedur Penelitian. Rineka Cipta, Jakarta. 
Bungin, Burhan. 2011. Metodologi Penelitian Sosial Format-Format Kuantitatif dan Kualitatif. Airlangga, Surabaya.

C. Scott, James. 1976. Moral Economy of Peassant: Rebellion and Subsystem in Souteast Asia. New Haven, London.

Chalil, Moenawar. 1970. Definisi dan Sendi Agama. Bulan Bintang, Jakarta.

Daradjat, Zakiah. 1973. Peran Agama dalam Kesehatan Mental. Guunung Agung, Jakarta.

\section{Bulan Bintang, Jakarta.}

Deden Ridwan, M. 1999. Melawan Hegemoni Barat: Ali Syari'ati dalam Sorotan Cendekiawan Indonesia. Lentera, Jakarta.

Edi Ekadjati, S. 1995. Kebudayaan Sunda: Suatu Pendekatan Sejarah. Pustaka Jaya, Jakarta.

Ellwood. 1988. History of Social Philosophy. Prentice Hall Inc, New York.

F. O'dea, Thomas. 1995. Sosiologi Agama. Rajawali Press, Jakarta.

Furchan, Arif. 1982. Pengantar Penelitian dalam Pendidikan. Usaha Nasional, Surabaya.

Giddens, Anthony. 1986. Kapitalisme dan Teori Sosial Modern; Suatu Analisis Karya Tulis Marx, Durkheim, dan Weber. UI Pres, Jakarta.

2005. Sosiologi: Sejarah dan Berbagai Pemikirannya. Kreasi Wacana, Yogyakarta.

Goldsmith, Marshall. 1998. Global Comunication and Communities of Chois, dalam Hesselbein, Francess, et al, The Community of The Future. Jossey-Bass Publishers, San Francisco.

Harun, Rochayat. 2007. Metodologi Penelitian Kualitatif. Mandar Maju, Bandung.

Hasan, Iqbal. 2002. Pokok-Pokok Materi Penelitian dan Aplikasinya. Ghalia Indonesia, Bogor.

Hendropuspito. 1983. Sosiologi Agama. Kanisius, Yogyakarta.

Hunt dan Metcalf. 1996. Ratio anf Inquiry on Society's Closed Areas. Albani, New York.
J Cohen, Bruce. 1992. Sosiologi Sebagai Pengantar. Rineka Cipta, Jakarta.

J. Moleong, Lexy. 2006. Metode Penelitian Kualitatif. Remaja Rosdakarya, Bandung.

Jalaluddin. 2002. Psikologi Agama. RajaGrafindo Persada, Jakarta.

K, Rachmad dan Dwi Susilo. 2008. Dua Puluh (20) Tokoh Sosiologi Modern. Ar Ruzz Media, Yogyakarta.

K. Nottingham, Elizabeth. 2002. Agama dan Masyarakat: Suatu Pengantar Sosiologi Agama. RajawaliPress, Jakarta.

Kahmad, Dadang. 2009. Sosiologi Agama. Remaja Rosdakarya, Bandung.

Kasiram, Moh. 2008. Metodologi Penelitian. UIN-Malang Press, Malang.

Kimbal, Charless. 2013. Kala Agama Jadi Bencana. Mizan, Bandung.

L. Berger, Piter \& Thomas Luckmann. 1990. Tafsir Sosial Atas Kenyataan: Risalah tentang Sosiologi Pengetahuan. terj. Hasan Basri. LP3ES, Jakarta.

L. Pals, Danel. 2012. Seven Theories of Religion. IRCiSoD, Yogyakarta.

Lawang, Robert. 1994. Pengantar Sosiologi. Universitas Terbuka Jakarta Press, Jakarta.

Lubis, Muchtar. 1988. Menggapai Dunia Damai. Yayasan Obor Indonesia, Yogyakarta.

M. Setiadi, Elly dan Usman Kolip. 2011. Pengantar Sosiologi Pemahaman Fakta dan Gejala Permasalahan Sosial: Teori, Aplikasi, dan Pemecahannya. Kencana Prenada Media Group, Jakarta.

M. Zeitlin, Irving. 1998. Memahami Kembali Sosiologi. Gajah Mada University Press, Yogyakarta.

Mansour, Fakih. 2003. Menegakkan Keadilan Kemanusiaan: Pegangan Untuk Membangun Gerakan HAM. Insist Press, Yogyakarta.

Miall, Hugh dkk. 2002. Resolusi Damai Konflik Kontemporer: Menyelesaikan, Mencegah, Mengelola, dan Mengubah Konflik Bersumber Politik, Sosial, 
Agama, dan Ras. Rajawali Press, Jakarta.

Moelyono, Anton. 1949. Tata Bahasa Baku Bahasa Indonesia. Balai Pustaka, Jakarta.

Muchlas. 1999. Perilaku Organisasi. Aditya Media, Yogyakarta.

Mukhtar, Aflatun. 2001. Tunduk kepada Allah. Khazanah Baru, Jakarta.

Narbuko, Chalid dan Abu Ahmadi. 2007. Metodologi Penelitian. Bumi Aksara, Jakarta.

Narwoko, Dwi dan Bagong Suyanto. 2005. Sosiologi Teks Pengantar dan Terapan. Kencana Prenada Media Group, Jakarta.

Nasution, Harun. 1985. Islam Ditinjau dari Berbagai Aspeknya, Jilid I. UI Press, Jakarta.

Nata, Abudin. 2012. Metodologi Studi Islam. RajaGrafindo Persada, Jakarta.

Norma Permana, Ahmad. 2000. Metodologi Studi Agama. Pustaka Pelajar, Yogyakarta.

Parsons, Talcott. 1937. Stucture of Social Action. McGraw-Hill, New York.

Penyusun, Tim. 2008. Ensiklopedia Islam, Jilid I. Ichtiar Baru Van Hoeve, Jakarta.

Pluit dan Rubin. 2004. Teori Konflik Sosial. Pustaka Pelajar, Yogyakarta.

Poerwadinata. 1976. Kamus Umum Bahasa Indonesia. Balai Pustaka, Jakarta.

Priyono dan Ilyas Hasan. 1988. Tantangan Dunia Islam Abad 21: Menjangkau Informasi. Mizan, Bandung.

Purwanto. 2008. Metodologi Penelitian Kualitatif. Pustaka Pelajar, Yogyakarta.

R. Minnery, Jhon. 1985. Conflict Management in Urban Planning. Gower Publishing Company Limited, Hampshire.

Ritzer, George dan Douglass J. Goodman. 1988. Modern Sociological Theory. The McGraw-Hill Companies Inc, Singapur.

Ritzer, George. 1992. Sosiologi Ilmu Pengetahuan Berparadigma Ganda. RajawaliPress, Jakarta.
Saeffullah Fatah, Eep. 1994. Masalah dan Prospek Demorasi di Indonesia. Ghalia, Jakarta.

Saifuddin Anshari, Endang. 1992. Pendidikan Agama Islam di Perguruan Tinggi. Rajawali Press, Jakarta.

Saifuddin Anshari, Endang. 2009. Ilmu, Filsafat, dan Agama. Bina Ilmu, Surabaya.

Sihombing, M Justin. 2005. Kekerasan Terhadap Masyarakat Marginal. Narasi, Yogyakarta.

Soegiman, Hari. 1990. Peranan Ilmu Sosial. Restu Agung, Jakarta.

Soekanto, Soejono. 2012. Sosiologi Suatu Pengantar. RajaGrafindo Press, Jakarta.

Soekanto, Soerjono. 1993. Kamus Sosiologi. RajaGrafindo Persada, Jakarta.

Stewart. 1985. American Cultural Patterns: A Cross-Cultural Perspective. Intercultural Press, America.

Sugiyono. 2006. Metode Penelitian KulaitatifKuantitatif dan $R \& D$. Alfabeta, Bandung.

Suharto, Edi. 2010. Membangun Masyarakat Memberdayakan Rakyat. Refika Aditama, Bandung.

Suprayogo, Imam. 2003. Metodologi Penelitian Sosial-Agama. Rosdakarya, Bandung.

Surbakti, Ramlan. 1992. Memahami Ilmu Politik. Grasindo, Jakarta.

Sururin. 2004. Ilmu Jiwa Agama. RajaGrafindo Persada, Jakarta.

Suryabrata, Sumardi. 1998. Metodologi Penelitian. RajaGrafindo, Jakarta.

Susan, Novri. 2010. Pengantar Sosiologi Konflik dan Isu-Isu Konflik Kontemporer. Kencana, Jakarta.

Susan. 2010. Pengantar Sosiologi Konflik dan Isu-Isu Konflik Kontemporer. Kencana, Jakarta.

Thaha. 1999. Konteks Berteologi di Indonesia Pengalaman Islam. Paramadina, Jakarta.

Wignjosoebroto, Soetandyo. 2002. Hukum Paradigma, Metode dan Masalah. Elsam dan Huma, Jakarta. 
Y Helmut, Bunu dan M. Busro. 2012. Sosologi Masyarakat Pesisir. Jenggala Pustaka Utama, Surabaya.

Yin, R. K. 1987. Case Study Research: Design and Methods. SAGE Inc, Bavery Hill California.

Zainuddin, M. 2011. Metodologi Penelitian Kefarmasian dan Kesehatan. Airlangga University Press, Surabaya.

Zuriah, Nurul. 2006. Metodologi Penelitian Sosial dan Pendidikan. Bumi Aksara, Jakarta.

\section{Jurnal}

McLelland. 1973. "Testing for Competence Rather than Intelegence". American Psychologist. Vol. 28. No. 1. hlm. 114.

Moehtadi, Fathoni. September 2015. "Konflik Poso: Suatu Anatomi". Jurnal Dinamika Masyarakat, Edisi II.

Mubit, Rizal. Juni 2016. "Peran Agama dalam Multikultaralisme Masyarakat Indonesia". Episteme, Vol. 11, No. 1.

Rusnandar, Nandang. 2000. "Sistem Pengetahuan Masyarakat Sunda: Makna Pendidikan di Balik Permainan Anak", Penelitian. Edisi 22. hlm. 1-35.

Sidi, Purnomo. 2014. "Krisis Karakter dalam Perspektif Teori Struktural Fungsional". Pembangunan Pendidikan: Fondasi dan Aplikasi. Vol. 2 No. 3, Jakarta. hlm. 1-16.

\section{Hasil Penelitian}

Klemens, Mere. 2007. "Nilai-Nilai Budaya, Fungsi, dan Makna Simbolik Rumah Adat Keo dalam Konteks Perubahan Masyarakat di Desa Lajawajo Kecamatan Mauponggo Kabupaten Ngadha-Flores-Propinsi Nusa Tenggara Timur (NTT)", Disertasi Doktoral. UNMER, Malang.

\section{Internet}

Aceng. "Kota Bandung Raih Penghargaan Sebagai Smart City”, dalam http://www.pikiranrakyat.com/bandung- raya/2017/05/23/kota-bandung-raihpenghargaan-sebaga-i-smart-city-ataukota-pintar-401747. Diakses Pada 1 Februari 2018. Pukul 05.15 WIB.

Adinda Purnama Rachmani. "Bandung Siap Jadi Kota Teknologi”, dalam http://m.liputan6.com/properti/read/2368677/bandu ng-siap-jadi-kota-teknologi. Diakses Pada 1 Februari 2018. Pukul 05.00 WIB.

Anonim. Badan Meteorologi Klimatologi dan Geofisika Tahun 2012. Dalam portal.bandung.go.id/geografi-kotabandung. Diakses pada 29 September 2017 Pukul 05.10 WIB.

Anonim. Demografi Kota Bandung. Dalam portal.bandung.go.id/geografi-kotabandung. Diakses pada 29 September 2017 Pukul 04.50 WIB.

Anonim. Demografi Kota Bandung. Dalam portal.bandung.go.id/geografi-kotabandung. Diakses pada 29 September 2017 Pukul 05.20 WIB.

Hangger Hidayanto. "Kota Bandung”, dalam http://hanggerh20.blogspot.co.id/2011/05/kota-bandung.html? $\mathrm{m}=1$. Diakses Pada 1 Februari 2018. Pukul 05.17 WIB.

Sysadmin. Sekilas Sejarah Kota Bandung, dalam portal.bandung.go.id/sekilassejarah-kota-bandung. Diakses pada 29 September 2017 Pukul 05.00 WIB.

\section{Koran}

Wildan, Dadan. "Perjumpaan Islam dengan Tradisi Sunda" (Pikiran Rakyat, Bandung, 26 Maret 2003).

\section{Hasil Wawancara}

Wawancara dengan Ustadz Abin Inwasli, Selaku Pemuka Agama Islam Karasak Kota Bandung. Pada 15 Maret 2018 Pukul 10.00 WIB.

Wawancara dengan Dikdik, Selaku Bidang Kewaspadaan Daera Kesbangpol Jawa Barat Pada 7 Maret 2018 Pukul 11.00 WIB. 
Wawancara dengan Ustadz Robi, Selaku Pemuka Agama Islam. Pada 17 Maret 2018 Pukul 11.00 WIB.

Wawancara dengan Pendeta Endar, Selaku Pemuka Agama Katolik. Pada 17 Maret 2018 Pukul 09.00 WIB.

Wawancara dengan Solihin, Selaku Bidang Fungsional Umum Kesbangpol Wilayah Jawa Barat. Pada 7 Maret 2018 Pukul 11.30 WIB.

Wawancara dengan Ustadz Amang, Selaku Pemuka Agama Islam Masyarakat
Kawaluyaan. Pada 18 Maret 2018 Pukul 10.00 WIB.

Wawancara dengan Pendeta Tony, Selaku Pemuka Agama Gereja BKP. Pada 18 Maret 2018 Pukul 13.00 WIB.

Wawancara dengan Ustadz Hamdan, Selaku Pengurus DKM Masjid Jami Cisaranten Baru I. Pada 19 Maret 2018 Pukul 09.00 WIB.

Wawancara dengan Ade, Selaku Bidang Fungsional Umum dan Humas Kemenag Kota bandung Jawa Barat. Pada 16 Maret 2018 Pukul 13.00 WIB. 